\title{
A REFLECTION GENERAL ABOUT OF SOCIAL CONFLICT IN MEXICO AS A GENERATOR OF REGIONAL VIOLENCE
}

\section{UMA REFLEXÃO GERAL SOBRE O CONFLITO SOCIAL NO MÉXICO COMO UM GERADOR DE VIOLÊNCIA REGIONAL}

\author{
Miguel Ángel Vite Pérez ${ }^{1}$
}

\begin{abstract}
The objective of this article is to examine the ways in which violence, coercion, and impunity in Mexico are reshaping the concept of state. These dynamics are at odds with the widespread belief that the legal framework and multi-party system that characterized the transition to democracy in the country helped to build a modern and democratic state.

Through a close examination of some of the mechanisms of control that the Mexican government devised and implemented in addressing the armed social conflict in Tierra Caliente (Michoacán), this article discusses the types of control that the government has developed and how they have resulted in a fragmented approach to dealing with situations of armed social conflict throughout the country.
\end{abstract}

Keywords: Social fragmentation, state control, armed conflict, legality, illegality

\section{Resumo}

O objetivo deste artigo é examinar as maneiras pelas quais a violência, coerção e impunidade no México estão redefinindo o conceito de Estado. Essas dinâmicas estão em desacordo com a crença generalizada de que o enquadramento legal e o sistema multi-partidário que caracterizou a transição para a democracia no país ajudaram a construir um Estado moderno e democrático.

Por meio de um exame atento de alguns dos mecanismos de controle concebidos e aplicados pelo governo mexicano para abordar o conflito social armado em Tierra Caliente (Michoacán), este artigo discute os tipos de controle que o governo tem desenvolvido e como eles resultaram em uma abordagem fragmentada de lidar com situações de conflito social armado em todo o país.

Palavras-chave: fragmentação social, o controle do Estado, os conflitos armados, a legalidade, a ilegalidade

\footnotetext{
${ }^{1}$ Doctor en Sociología por la Universidad de Alicante, Espanha. Mestre en Desarollo Urbano por El Colégio de México. Professor do Instituto Politécnico Nacional de México. E-mail: miguelviteperez@yahoo.com.mx
} 


\section{INTRODUCTION}

The collapse of the Mexican government's control of criminal activity associated with drug trafficking has been linked to the end of the one-party-rule system that prevailed in the country for over 70 years. The so-called transition to democracy paved the way for the current system of alternating political parties (Astorga, 2015).

In reality, however, it was a political transition characterized by changes and reforms in state institutions that were drawn up through various agreements. These resulted in new rules for a plural political elite to access and exercise power, all of which was guaranteed through an impartial electoral system (Woldenberg, 2012).

The violence that flourished during the transition to democracy resulted from two main factors: on the one hand, from the unwillingness of certain political groups to accept a multi-party system and their efforts to rebuild the hegemonic one-party system that had been swept out of power; on the other, from armed social actors that sought a radical transformation of state institutions. These two factors were evident in the assassination of presidential candidate Luis Donaldo Colosio, of the Institutional Revolutionary Party (PRI), on January 27, 1994, and the declaration of armed rebellion by the Zapatista Army of National Liberation in Chiapas on January 1 of the same year (Woldenberg, 2012: 91-99).

In that context, violence was seen as a problem tied to the crisis facing PRI hegemony in light of the rapid spread of political party alternation at the municipal and state levels throughout the country. Violence was also considered to be a manifestation of an unwillingness on the part of political and social leaders to accept the "new rules" of democracy, especially as they based their power on mass mobilizations and the use and abuse of legal as well as illegal means for personal and communal benefits (Durand, 2010).

Within this context, the idea that violence was a constitutive element of the Mexican state was not considered, even though the government had abandoned its role as an agent in the country's economic development and had ceased to guarantee social rights while it adopted a new role in creating regional markets for new transnational and neoliberal economic development (Escalante, 2015).

While violence was considered a negative force, it was deemed to be a temporary one that manifested the institutional (organizational) disintegration of an authoritarian social order as 
newer democratic institutions became better established and the plural political elite learned the new rules to compete for power.

Nevertheless, the pressures of economic globalization put an end to the notion of the state as guarantor of social wellbeing. Thereafter, a "good government" would gain legitimacy only as it intervened in the face of the inadequacies or inefficiencies of market or social self-regulation mechanisms, and acting in collaboration with a broad range of civil organizations (Chevallier, 2011).

In this context, the state fosters individual and organizational initiatives, establishing management mechanisms suited to the issues they address. It thereby recasts its traditional functions of maintaining public order and social cohesion (Chevallier, 2011: 89-92).

The state's role in protecting social cohesion from internal and external enemies was thus linked to improving its punitive functions in light of growing social uncertainty as the welfare state ceased to be the guarantor and organizer of social and financial wellbeing in countries both in the North and the South (Lyon, 2004: 135-136).

The state's pressing need to protect national social cohesion through punitive force stems from the globalization of surveillance, a current trend in countries both of the developed North and those in the underdeveloped South. This trend has been exacerbated by specific events such as the September 11, 2001 terrorist attacks of the World Trade Center towers in New York City as well as by more diffuse yet pervasive issues such as the so-called "war on drugs" (Lyon, 2007).

Social risks have therefore become globalized because state institutions cannot control them. The cost of dealing with such risks is high and must be shared either individually, through a group or through private companies. This is why we need more accurate and reliable information to develop new mechanisms of alert and surveillance (Lyon, 2004: 137).

A surveillance society begins to takes shape when information on individuals pertains not only to their income and consumer preferences, but also to their biometric characteristics, and is stored in technology used for commercial, national security or criminal purposes, among others. This breaches the boundary between legality and illegality and state control over individual information has thereby been legitimized, seizing upon the argument of the "uncontrolled" and proliferating risk that various social actions inside and/or outside the country represent to national cohesion (Lyon, 1994).

In light of the worldwide scope of this situation, violence manifests itself in many different ways and grows quickly. As a result, the state is challenged in its ability to control it or prevent it because social behavior is not uniform and there is no single reliable technology (Collins, 2008). 
What is happening, and I posit this as a general hypothesis, is that the postmodern state ${ }^{2}$ is reshaping its punitive function through professionalization and technological expertise as it confronts a massive increase in the number of individuals and groups cast out of traditional social and economic orders (Sassen, 2015).

In the case of Mexico, the state's approach to reshaping its punitive function follows a particular model: the violent control of gray zones or illegal territories or their margins. ${ }^{3}$ These zones, organized and managed through illegal criminal activity, used to be hidden or semi-hidden but are now clearly visible. The authoritarian regime of the one-party system used to control these zones out of the public eye, subordinating them to its rules (Pansters, 2012).

Violence has been a historically constitutive element of the Mexican state. This is reflected in the emergence of narratives about crime whereby violence has served to strengthen a collective representation in opposition to the rule of law. This has made it possible to tolerate, legitimize and live in exceptional situations characterized by social injustice and the discretional application of penal justice (Domínguez, 2015).

With this in mid, I propose an interpretation of Mexican violence considered as a collective event that has been used to legitimize the state's punitive function in a neoliberal globalized economic context (Van Dijk, 2011: 56-57).

This article is divided into three sections. In the first one, I analyze the concepts of social fragmentation and state control in a context characterized by uncertainty and risk focused through punitive policies. Based on this analysis, in the second section of the article I provide a sociological interpretation of the armed events conducted by the self-defense organizations of Tierra Caliente (Michoacán). Finally, in the third section, I offer some closing thoughts, highlighting the possible relationship between the punitive policies of the Mexican state and neoliberal public policies of social control.

\footnotetext{
${ }^{2}$ From a sociological perspective, postmodernity is tied to social differentiation and fragmentation. From an economic perspective, it is linked with the end of industrial activities, which are replaced with service and tertiary activities (based on the development of information and communication technologies). In terms of the political realm, it is associated with the erosion of the State's sovereign power (Lyon, 2005: 27).

${ }^{3}$ Gray zones, illegal territories or the margins of the State are ambiguous spaces that lack defined borders and are characterized by clandestine social relations undertaken between legal state actors and illegal actors with the objective of personal/particular benefits (Auyero, 2007).
} 


\section{SOCIAL FRAGMENTATION, RISK AND VIOLENCE}

The crisis of the world of work brought about social fragmentation, especially because social rights are no longer the organizing principle of a salaried society (Dubet, 2011).

The dissociation between work and social rights also signaled the beginning of job uncertainty. Not only did low salaries and temporary work displace life-long employment, but social rights were no longer part of the package (Ochando, 2002).

For decades, social rights were guaranteed through a system of collective social welfare that the state implemented and managed as it fulfilled other social roles through redistribution policies (Offe, 1990).

From a sociological perspective, the fundamental importance of salaried work went well beyond the social differences outlined through different salaries. It was, above all, a social inclusion mechanism of universal scope (Castel, 2004).

According to Castel (1997: 42-53), the widespread nature of salaried work resulted in social integration and cohesion, creating certainty about the future despite the negative consequences of unemployment and impoverishment -dynamics within capitalism that, paradoxically, foster uncertainty.

Risks associated with unemployment and workplace injuries, as well other unrelated ones such as illness and old age, were addressed by public policies that sought to minimize their negative effects on individuals.

In other words, the state was responsible for building and enabling the conditions and possibilities for individuals to develop their potential.

The development of such potential, according to Castel and Haroche (2003), created social individuals because the state was responsible for providing the means to achieve it.

As salaried work lost its power of social inclusion, social vulnerability started to grow, hand in hand with uncertainty. The ability to makes plans for the future all but disappeared since the workplace turned into a transient space frequented for a few days or months, and workers were granted no social rights or enough income to meet their social reproduction needs.

In light of the lack of social protections, risk and uncertainty came to be articulated as the social fear of being unemployed and falling into poverty. Thus, institutions in the welfare state lost their ability to endow individuals with social attributes (Bourdieu, 2002). 
If state institutions are unable to generate social individuals, they foster situations in which not only social protests flourish, but also collective violence (Fillieule and Tartakowsky, 2015: 91).

The precedents of collective violence, however, could traced to the intensification of social conflict, which, as Dubet and Martuccelli (2000) remark, has its roots in the diminished ability of traditional institutions such as the family and school to generate social cohesion.

The crisis of modern society is also a result of a process of deinstitutionalization. This has led to a diminished capacity to integrate individuals into society, thereby accelerating social inequalities associated with a variety of needs in terms of material and cultural reproduction (Dubet, 2000).

An individual who lacks institutional supports is vulnerable and is therefore at risk of turning into an excluded or marginalized one who occupies a gray zone where ambiguity dissolves the boundaries between what is legal and illegal, between what is allowed and what is forbidden. In this liminal zone, violent social relations become "naturalized" in everyday life (Davis, 2007: 15$35)$.

The transformation of salaried work as the source of social rights has its historic antecedent in the invention of the social, which, according to Donzelot (2007: 15-26), consisted in the restoration of solidarity through the state's social function as a means to render the equality of the democratic regime compatible with real inequalities created by a market economy. The social was an element constructed to mediate between the political and the civil in order to mitigate political passions that led to confrontation or violence.

Karl Polanyi (2007) argued that the commodification of nature and of various aspects of social life endangered nature and even human life, therefore commercial activity ought to be regulated by the state. He did not, however, consider the significance of the State's social function as a limit to capitalism's trend toward international commodification.

That said, the causes of social fragmentation are not restricted to the crisis confronting the welfare state or work as an institution of solidarity based on social rights. The roots of such fragmentation can be traced to the realm of informal work comprising a range of heterogeneous activities, which has unmoored the concept of work from its narrow and precise definition as formal industrial employment (Mingione, 1993: 113-114).

In Mingione's view (1993: 115-116), work linked to the social has generated confusion because only work activity protected by the State through its social policies is relevant. There are, 
however, other economic activities that generate wealth for some and poverty for others, and these are located on the margins of state policies and the formal market economy.

For some countries of the global South, though, the increase of various informal work activities is not a indication of the crisis facing the world of work or of the decline of the state's social functions. Rather, it is one of the ways in which the state has managed to accomplish the task of creating conditions of employability for its population.

Social stability is achieved through a fine balance whereby the state's functions of governability manage to be in step with private actors' particular actions in order to produce an unequal distribution of the benefits of economic development. The concepts of rule of law and meritocracy lose their value because such development is based on personal loyalties, influence peddling, violence, and coercion (Hibou, 2013).

In Mexico, government functionaries have in some instances substituted the rule of law, partially or in its entirety, or subordinated it to their particular personal interest thereby giving place to exceptional situations where state law has been displaced in favor of loyalty and corruption.

For Durand (2010: 36), social exclusion reproduces zones of illegality because there is no legal regulation. Social relations operate instead within a framework defined by case-by-case arrangements aimed at deriving benefits on the fringes of institutions.

This dynamic shapes a situation of exception that, in turn, fosters further social exclusion such as poverty and misery. In other words, a state of exception means the existence of an uncertain legal framework for citizens and the absence of social attributes granted to individuals through institutions.

Another term to name social life in the gray or illegal zones would be state of exception, as official state law is not part of social relations and institutions have not managed to create social individuals. In these zones, individuals operate isolated from formal political and economic mechanisms, though under certain conditions may interface with them if deemed beneficial (Agamben, 2007: 14-15).

The intersection between the legal and illegal realms in Mexico has shaped a particular fragmented order that reflects a variety of experiences and social practices throughout the country, which state authorities address as social conflicts and tend to manage outside the official legal framework (Duhau and Giglia, 2008: 11-17). 
In countries of the global North, social fragmentation results from the social vulnerability ushered in by the end of job security and of associated social benefits. The uncertainty surrounding employment, and work more broadly, is a consequence of the crisis of the world of work and the diminished role of the state as provider of social safety nets. This dynamic began to take shape in the mid 1970s when the Fordist industrial production model wore out, giving way to state deregulation of economic activity (Steger, 2009: 46). ${ }^{4}$

As the relationship between salaried work and social benefits dissolved, social practices that were based on them also disappeared. Informal work has thus flourished in illegal zones, administered by both government authorities and criminal groups that fight amongst themselves to extract profits and/or benefits.

In the case of countries in the global South, and perhaps overgeneralizing a bit, social fragmentation is associated to elements beyond the crisis of the state's social functions. Specifically, there are exceptional situations in which social relations are not regulated through the law, but through particular regulations based on formal policies or in complicity with them, sharing benefits and advantages.

On the one hand, the state has not managed to provide for the wellbeing of the poor, who therefore have had to devise their own strategies for survival through the informal sector, for instance. On the other, the state has labeled all illegal activity as criminal, though in some cases it controls access to some of the benefits originating from the illegal realm in an effort to legitimize its social commitment to the poor.

This is why the state has oscillated between repression and permissiveness, thereby demonstrating that its institutional capabilities to bolster the rights of citizens, rich or poor, are weak or precarious (Durand, 2010: 49-51).

In the global North, according to Beck (2002), social risks are due to the following: the state's diminished capability to provide social safety nets, the socialization or widespread allocation of risk stemming from the lack of social policies, and the individualization of risk through its commodification by insurance companies. As such, the concept of risk is associated with the globalization of the neoliberal economic model.

\footnotetext{
${ }^{4}$ Neoliberal thought has reorganized economic theory and influenced the design of national economic policies, fostering the construction of a worldwide ideology that justifies the advantages of free markets and liberal democracy (Chomsky, Cypher, Foster, Hart-Landsberg, Herrera, Navarro, and Vogel, 2007).
} 
The expansion of individual risks and the management of risk as a commodity, however, has not managed to guarantee public safety. Rather, it has fostered the emergence of a surveillance state in the global North (Foessel, 2011).

Nevertheless, the state cannot control everything and neither can it be a part of the various mechanism that reproduce social practices, which is reflective of the demise of its social function as well as of the deregulation of economic activity. Concomitantly, national security increasingly depends on surveillance performed with state-managed technology.

The surveillance state, according to Foessel (2011: 17-27), uses technology to assert its presence in public spaces and even in private businesses. Moreover, it transforms private citizens into surveillance tools through fear that the enemy may be the person next door.

Public safety thus becomes a public matter that can maintain national unity through a common objective: to protect oneself from internal and external enemies. This further legitimizes the surveillance state (Foessel, 2011: 28-29).

Finally, public safety is an issue for the surveillance state, whose responses involve violence because it assumes that the enemy will use violence to destroy private property and attack owners or consumers (Sofsky, 2006).

The belief that individualized insecurity is a public matter linked to the existence of real or imaginary enemies has made it difficult to see that fears originate in the inability of institutions to integrate or include the individuals cast out of the inclusion zone. This has broadened the space of vulnerability, and the individuals who live within it are close to a violent break with the social (Augé, 2014: 13-29).

The social fear of risk articulated as violence underscores the absence or weakness of institutional protections that is further evidenced when individuals or organizations take matters into their own hands I order to deal with those who contravene social order (Castel, 2013: 34-35).

In the case of Mexico, social fragmentation points to a social system of reciprocal exclusions and uneven inclusions. In other words, as Saraví remarks (2015: 21-22), a process of inclusion that enables differentiated access to benefits in order to create a system of exclusion that marginalizes those who do not have access to those benefits. This has led to a situation of social inequality that fosters conflictive social cohesion, and in some cases such conflict is manifested through violence. 


\section{FRAGMENTATION OF THE ARMED SOCIAL CONFLICT IN MEXICO}

The system of unequal inclusion and reciprocal exclusion in Mexico, which has its institutional foundation in the state, stems from a dynamic of social control based on a corporate organization of social interests that are an integral part of the PRI.

Moreover, the state organized the use of force as another method to control social conflicts, thereby creating an environment conducive to the widespread growth of coercion, discretionary behavior, violence, impunity, and general insecurity (Gledhill, 1999).

While violence and coercion are not an integral part of the legal system, the political and financial elites have used them as a means to organize their interests in a discretionary manner, thus reproducing the system of unequal inclusion and reciprocal exclusion limitlessly. In a situation of exception, furthermore, legal sanctions lose their validity (Gledhill, 1999: 199-230).

In fact, Gledhill (1999: 249-251) argues that the Mexican state of the democratic transition had a "dark side" populated by "shadows of power" that were "disguised" within the institutional framework of the law. That is, illegality was a way of governing and deriving the benefits of political power while repressing any trace of opposition within the plural political elite, as was the case with the violent death of PRI presidential candidate Luis Donaldo Colosio.

Similarly, Pansters (2012: 3-8) remarks that the various violent incidents that have taken place in Mexico so far this century have the same characteristics as they are the result of violence, coercion, insecurity, and impunity that the Mexican state has denied even though these elements have reshaped its national security agenda.

In my view, and according to Nuñez (2012: 13-17), those elements have enabled the Mexican state to legitimize its new punitive function in its battle against drug trafficking and organized crime. Since the 1990s, the criminalization of organized crime has been justified through a state ideology articulated as the necessary steps to "rescue" territory "controlled" by the illegal realm, and the only means to achieve it is through the use of the armed forces.

A number of social groups shared the state's perception that there were towns and localities throughout the country that were held and managed by organized crime leaders. This is a phenomenon that Buscaglia (2015) has attributed to power vacuums.

In other words, the criminal element performs social and governmental functions in territories where state authority is absent either because it does not govern or because it has 
become subordinated to the interests of organized crime. Meanwhile, the police in such a context merely serves to protect illegal business. ${ }^{5}$

Indeed, public policies are absent in a number of areas throughout Mexico, which has enabled the illegal realm to create substitute mechanisms of temporary social cohesion. This, in turn, has further highlighted the gap between government and regional issues as well as revealed the state's "dark side" for what it is: targeted violence and coercion carried out by armed groups combatting criminals, which shapes a new local order whereby the community keeps matters in check with weapons.

In the words of Bernardo Secchi (2015: 19-24), the absence of state policies in various regions has fostered the emergence of a sense of differentiation and separation that renders the chasm between wealth and poverty glaringly visible. Social fragmentation has grown exponentially in Mexico as a result of the dynamic of inclusion and exclusion, and has been further bolstered by an assortment of ineffective approaches to address and solve the problem. Local and narrowlyfocused social assistance programs along with the lack of a collective sense of nation has led to uneven development, especially as some regions have independently developed strong ties to world markets and thus prosper as part of a broader global territory.

Mexico's illegal regions, territories or spaces where illegality has prospered, are the consequence of the absence of public policies for development and for redistribution of wealth. Moreover, they are the pernicious symptom of the neoliberal economic policies that the various administrations have implemented in the country since the 1982 crisis.

The case of Tierra Caliente (located in the southern portion of the state of Michoacán) is representative of these issues so I will discuss it in some detail as it provides a concrete reference. ${ }^{6}$ Tierra Caliente became an illegal zone due to the lack of agricultural development policies and to the autonomy that drug trafficking groups achieved as the power of local police and other authorities eroded (Maldonado, 2010).

The state's mechanism to control illegality, part of that "dark side" mentioned above,

\footnotetext{
${ }^{5}$ Urban sociologist Mike Davis does not support the idea of power vacuums because, as he points out, the communities on the outskirts of Morocco, for instance, which lack public services and are inhabited by the unemployed and people who work in the informal sector or who are involved in the drug trade, have managed to organize their daily life in their own particular way without government intervention. In fact, this demonstrates the state's institutional weakness to fulfill its most basic functions in terms of providing social welfare and security to the poor (Davis, 2000: 34).

${ }^{6}$ The region of Tierra Caliente comprises the following municipalities: Apatzingán, Parácuaro, Nueva Italia, Buena Vista, Tomatlán, Tepalcatepec, Aguililla, Gabriel Zamora, and Churumuco.
} 
contributed to the growth of local drug trafficking activities as organized crime leaders decided to operate within the framework of the state's formal power structure when faced with their only two choices: to die or to suffer the consequences of legal punitive action (Astorga, 2015: 20-21).

The socioeconomic organization of Tierra Caliente is marked by a history of violence inflicted on local farmers by livestock and agricultural producers looking to seize their lands for commercial exploitation. Additionally, there is also a history of state violence, exerted through the army to control social conflict. The justification for this type of violence is, on the one hand, the alleged protection of public safety in light of the number of robberies and murders in the area, and, on the other, the false belief that individuals were "taking care" of their problems through violent means (Maldonado, 2015: 80-83).

The fact is that, in the past as well as at the present time, violence and insecurity appeared as two elements that were an integral part of the state's punitive intervention.

There is, however, a new element in the Tierra Caliente case: community-based organization of armed violence --which operates within the ideological framework of punishing those who foster regional insecurity--, coincides with the federal government's armed approach to dealing with criminals. And both actors identify the criminal element as drug traffickers (Gil, 2015).

The links between drug traffickers and government authorities, which in the past remained hidden within the corporate and authoritarian legal and institutional framework, surfaced through campaign financing of the various political parties. It helped, in fact, to strengthened ties with public safety and public works functionaries (Hernández, 2013: 6-7).

At the same time, the fragmentation of criminal organizations has allowed for the growth of different groups that have controlled in an irregular fashion the production and trafficking of different types of drugs. They have thus formed alliances with municipal presidents and even with the minister of government of then-governor Fausto Vallejo (PRI). ${ }^{7}$

It must be noted that the transformation of the main drug trafficking organization in the Tierra Caliente region, The Knights Templar, is not a simple matter of a colorful new name, but of a

\footnotetext{
7 In the 1980s and 1990s it was the organization of the Valencia brothers, grocery store owners, whose network of friends and relatives enabled them to be accepted and respected throughout the region despite their marihuana and cocaine trafficking activities. Thereafter, it was replaced by another local group that originated as a vigilante group and a religious sect in 2006, called Familia Michoacana. In December 2010, with the death of its leader, Nazario Moreno González, alias "El Chayo," it reorganized under new leadership (that of Servando Gómez, alias "La Tuta"), at which time it adopted a new name: The Knights Templar (Gil, 2015: 74-123).
} 
complex combination of its activities as a religious sect with those of a vigilante group. This has enabled the organization to profit not only from drug trafficking but also from extorting quotas from business people and landlords, and also from skimming a share of the profits of municipal and livestock fairs (Gil, 2015: 127).

The Knights Templar were also entrenched in municipal and state governments, where they had a number of representatives. Additionally, they were involved in formal economic activities for personal gain.

Violence and coercion, once considered methods wielded almost exclusively by the state, are now are commonly used among drug trafficking groups when they believe that there are great benefits to it, especially if it has an impact on the social organization of their particular locality. The participants of this illegal business, furthermore, are the inhabitants of the various communities of Tierra Caliente (Castellano and Gil, 2013: 11-12).

The present-day militias in Tierra Caliente began to take shape when the inhabitants of the region decided to put end to the stranglehold of the Knights Templar Cartel. They were fed up with the organization's quotas on all economic and commercial activities as well as with their coercive methods to extort them from ranchers and business owners who refused to pay, which included the rape of spouses and daughters (Gil, 2013:6).

The conflict that arose between the Knights Templar and the people's vigilante organizations allowed for the government to intervene by appointing a Commissioner to work alongside them, with the support of the Federal Police, to dissolve the Knights Templar. Part of the plan also involved bringing some of the members of the Knights Templar into the then newly formed people's militias. (Gil, 2015: 253-269).

The government's objective, thus, was to transform the vigilante groups fighting the Knights Templar into rural militia-style police forces, which meant legitimizing the state's punitive function against drug trafficking. However, the state exercised such a level of control that it managed to fuel even further the situations of insecurity leading to even greater fragmentation. While commonly attributed to power vacuums, what actually promotes such fragmentation is the absence of social protections and state institutions to address social needs that generally serve as the material support for the development of social individuals.

The state's approach to addressing the problem of insecurity and threats to public safety has been piecemeal and fragmented; as such, in Piñeyro's words, it is at best a '(...) firefighters' 
policy battling possible or real political fires and not a structural approach to them" (Piñeyro, 2010: 183).

\section{CLOSING THOUGHTS}

In Mexico, the state's punitive policy is an integral part of its strategy to combat organized crime, especially those groups involved in drug trafficking. The deployment of armed force in fighting criminal elements stems from changes undergone in penal systems around the world. From a sociological perspective, the use of force is aimed at creating greater social cohesion, however in a context where poverty and misery have been criminalized.

As a social representation, fear of crime serves to maintain social cohesion marked by insecurity and uncertainty, especially due to dynamics of social fragmentation that reproduce inequality.

Violence and coercion are constitutive elements of the Mexican state as they are the methods used to control social conflict, though up until relatively recently these they were not public, only in exceptional situations did they become clearly visible.

The transition to democracy in Mexico revealed that such methods, indeed, were not exceptional. Rather, they had a long history, yet had been concealed by the one-party system that ruled the country for the better part of the XXc.

The violence and coercion that so visibly occupy public space in present-day Mexico do not stem only from the crisis of the authoritarian corporate system of the ruling political regime in Mexico; they are also the consequence of the severance of the ties that linked drug traffickers, and organized crime in general, to the official state system in a subordinate dynamic. As the relationship unraveled, it enabled drug traffickers to enjoy greater autonomy in the management of their businesses.

Furthermore, media coverage of the violence and coercion that permeated everyday life also had a key role in uncovering the "dark side" of the Mexican state.

The state's means of social control in Mexico are violence and coercion. Citizen rights, social justice, and the rule of law supported by a judicial and penal systems are the exception.

Neoliberal public policies in Mexico have created markets and clients. Regional development, meanwhile, has been uneven because the internationalization of local economies has managed to produce some globalized zones whose success depends on ties to global markets. 
The punitive approach to crime fighting has become socialized. As the case of the Tierra Caliente militias demonstrates, this has proven a powerful element in the organization of armed collective action within the community, yet it has also enabled and further strengthened criminal activity of some of its members.

The community is part of the mechanism that reproduces violence and coercion. The state stepped in to institutionalize such activity when it transformed the local vigilante groups into a rural police force or militia. The Mexican state's fragmented approach in addressing public insecurity speaks to its lack of control of social and economic processes throughout the country. It is a discontinuous state that requires private agents to help it perform the task of governing.

\section{FUNDING}

This research received no specific grant from any funding agency in the public, commercial, or not-for-profit sectors.

\section{REFERENCES}

AGAMBEN, G (2007) Estado de excepción. Buenos Aires: Adriana Hidalgo editor.

AUGÉ, M (2014) Los nuevos miedos. México: Paidós.

ASTORGA, L (2015) “¿Qué querían que hiciera?" Inseguridad y delincuencia organizada en el gobierno de Felipe Calderón. México: Grijalbo.

AUYERO, J (2007) La zona gris. Violencia colectiva y política partidaria en la Argentina contemporánea. Buenos Aires: Siglo XXI Editores.

BECK, U (2002) La sociedad del riesgo global. Madrid: Siglo XXI Editores.

BOURDIEU, P (2002) Lección sobre la lección. Barcelona: Anagrama.

BUSCAGLIA, E (2015) Vacíos de poder en México. México: Proceso/Grijalbo.

CASTEL, R (2013) Políticas del riesgo y sentimiento de inseguridad. In Castel R, Kessler G, Merklen D and Murad N (eds) Individuación, precariedad, inseguridad ¿Desinstitucionalización del presente? Buenos Aires: Paidós.

(2004) La metamorfosis de la cuestión social. Una crónica del salariado, Buenos Aires: Paidós.

CASTEL, R and HAROCHE, C (2003) Propiedad privada, propiedad social, propiedad de sí mismo. Conversaciones sobre la construcción del individuo moderno. Rosario: HomoSapiens Ediciones. 
CASTELLANOS, F and GIL, J (2013) Las autodefensas se fortalecen y multiplican. Proceso 1934 (24): $10-12$.

CHEVALLIER, J (2011) El Estado posmoderno. Colombia: Universidad Externado de Colombia.

CHOMSKY, N; CYPHER, J; FOSTER, J; HART-LANDSBERG, M; HERRERA R; NAVARRO, V and VOGEL, R (2007) 25 años de neoliberalismo. Barcelona: Hacer Editorial.

COLLINS, R (2008) Violence. A Micro-sociological Theory. United States: Princeton Press.

DAVIS, M (2007) Ciudades muertas. Ecología, catástrofe y revuelta. Madrid: Traficantes de Sueños. (2000) Urbanismo mágico: los latinos reinventan la gran ciudad estadounidense. New Left Review (3): 25-51.

DUHAU, E and GIGLIA, A (2008) Las reglas del desorden: habitar la metrópoli. México: Universidad Autónoma Metropolitana Azcapotzalco/Siglo XXI Editores.

DOMÍNGUEZ, H (2015) Nación Criminal. Narrativas del crimen organizado y el Estado mexicano. México: Ariel.

DONZELOT, J (2007) La invención de lo social. Ensayo sobre la declinación de las pasiones políticas. Buenos Aires: Nueva Visión.

DUBET, F (2011) Repensar la justicia social. Contra el mito de la igualdad de oportunidades. Buenos Aires: Siglo XXI editores.

(2000) Les inégalités multipliées. Paris: Éditions de l'aube.

DUBET, F and MARTUCCELLI, D (2000) ¿En qué sociedad vivimos? Buenos Aires: Editorial Losada S. A.

DURAND, V (2010) Desigualdad social y ciudadanía precaria ¿Estado de excepción permanente? México: IIS-UNAM/ Siglo XXI Editores.

ESCALANTE, F (2015) Historia Mínima de el neoliberalismo. México: El Colegio de México, A. C.

FILLIEULE, O and TARTAKOWSKY, D (2015) La Manifestación. Cuando la acción colectiva toma las calles. Buenos Aires: Siglo XXI Editores.

FOESSEL, M (2011) Estado de vigilancia. Crítica de la razón securitaria. Madrid: Lengua de Trapo.

GIL, J (2015) Batallas de Michoacán. Autodefensas, el proyecto colombiano de Peña Nieto. México: Ediciones Proceso.

(2013) Peña Nieto, tras los pasos de Calderón. Proceso. 1908 (26): 6-10.

GLEDHILL, J (1999) Official Masks and Shadow Powers: Towards an Anthropology of the Dark Side of State. Urban Anthropology of Cultural Systems and World Economic Development 28 (3/4):199251. 
HERNÁNDEZ, A (2013) Quiénes y cómo gobiernan realmente en Michoacán. Proceso. 1931(3): 610.

HIBOU, B (2013) De la privatización de las economías a la privatización de los Estados. Análisis de la formación continua del Estado. México: Fondo de Cultura Económica.

LYON, D (2007) Surveillance Studies. An Overview. United States: Polity Press. (2005) Posmodernidad. Madrid: Alianza Editorial.

(2004) Globalizing Surveillance. Comparative and Sociological Perspectives. International Sociology 19 (2): 135-149.

(1994) The Electronic Eye. The Rise of Surveillance Society. United States: University of Minnesota Press.

MALDONADO, S (2010) Los márgenes del Estado mexicano. Territorios ilegales, desarrollo y violencia en Michoacán. Zamora: El Colegio de Michoacán.

MINGIONE, E (1993) Las sociedades fragmentadas. Una sociología de la vida económica. Más allá del paradigma del mercado. Madrid: Ministerio de Trabajo y Seguridad Social.

NÚÑEZ, E (2012) La tragedia del calderonismo. Crónica de un sexenio fallido. México: Grijalbo.

OCHANDO, C (2002) El Estado del bienestar. Barcelona: Ariel.

OFFE, C (1990) Contradicciones en el Estado de Bienestar. México: CNCA/Alianza Editorial.

PANTERS, W (2012) Zones of State-Making. Violence, coercion, and hegemony in TwentiethCentury Mexico. In Pansters W (editor) Violence, Coercion, and State-Making in Twentieth-Century Mexico. United States: Stanford University Press.

PIÑEYRO, J (2010) Las fuerzas armadas mexicanas en la seguridad pública y la seguridad nacional. In Alvarado A and Serrano M (coors) Los grandes problemas de México. Tomo XV. Seguridad nacional y seguridad interior. México: El Colegio de México, A. C.

POLANYI, K (2007) La gran transformación. Los orígenes políticos y económicos de nuestro tiempo. México: Fondo de Cultura Económica.

SARAVÍ, G (2015) Juventudes fragmentadas. Socialización, clase y cultura en la construcción de la desigualdad. México: FLACSO México/CIESAS.

SASSEN, S (2015) Expulsiones. Brutalidad y complejidad en la economía global. Buenos Aires: Katz.

SECCHI, B (2015) La ciudad de los ricos y la ciudad de los pobres. Madrid: Catarata.

SOFSKY, W (2006) Tratado sobre la violencia. Madrid: ABADA Editores.

STEGER, M (2009) Globalization. A very short introduction. Great Britain: Oxford University Press. 
VAN DIJK T (2011) Sociedad y discurso. Cómo influyen los contextos sociales sobre el texto y la conservación. México: Gedisa editorial.

WOLDENBERG J (2012) Historia Mínima de La transición democrática en México. México: El Colegio de México, A.C.

Trabalho enviado em 11 de maio de 2016.

Aceito em 05 de julho de 2016. 